\title{
Valorization of Passion Fruit Stalk by the Preparation of Cellulose Nanofibers and Immobilization of Trypsin
}

\author{
Yeimy A. Rodríguez-Restrepo ${ }^{1,2}$, Cristina M.R. Rocha ${ }^{2}$, José A. Teixeira ${ }^{2}$, and Carlos E. Orrego ${ }^{3 *}$ \\ ${ }^{1}$ Instituto de Biotecnología y Agroindustria, Departamento de Ingeniería Química, Universidad Nacional de Colombia, \\ Sede Manizales, Campus la Nubia Km 7 Via al Aeropuerto, Manizales 170003, Colombia \\ ${ }^{2}$ Centre of Biological Engineering, University of Minho, Campus Gualtar, Braga 4710-057, Portugal \\ ${ }^{3}$ Instituto de Biotecnología y Agroindustria, Departamento de Física y Química, Universidad Nacional de Colombia Sede \\ Manizales, Campus la Nubia Km 7 Via al Aeropuerto, Manizales 170003, Colombia
}

(Received December 11, 2019; Revised March 8, 2020; Accepted March 22, 2020)

\begin{abstract}
Fibers from passion fruit stalks were first recovered with a pulping and bleaching process. Two mechanical treatments were further applied to the fibers, homogenization (with and without ultrasound), and blender application. The effect of those treatments on fibers was evaluated. The chemical composition of the different stages of fibers undergoing treatment were measured according to TAPPI standards and were also analyzed by SEM, FTIR, and XRD. Trypsin was immobilized by adsorption and by covalent binding. The biocatalyst support-trypsin was evaluated in terms of immobilization yield, retention, and enzymatic activity. The experimental results demonstrated that the final cellulose concentration in the fibers was $44 \%$ higher than that in the raw stalks. The cellulose nanofibers obtained by homogenization presented a size distribution between $20-200 \mathrm{~nm}$, and the application of ultrasound did not show a significant effect on size (between 50 to $300 \mathrm{~nm}$ ). Trypsin immobilized using glycidol presented an immobilization yield of $67 \%$ and presented higher retention and enzymatic activity $(1.17 \pm 0.05 \mathrm{U} / \mathrm{mg}$ protein and $44.0 \pm 2.0 \%$, respectively). These results show that passion fruit stalks can be successfully used as a source of cellulose nanofibers and also can be used as carriers for the immobilization of trypsin.
\end{abstract}

Keywords: Passion fruit, Agro-industrial waste, Cellulose nanofiber, Immobilization, Trypsin

\section{Introduction}

Passion fruit is a short-cycle tropical fruit crop cultivated in Brazil, Colombia, Ecuador, northern Argentina, Paraguay and Peru [1]. It could be eaten fresh but is mostly juiced, pulped, or concentrated before consuming. In 2016, Colombia produced over 89,000 tons of passion fruit in a planted area of approximately 7,200 ha, with an average fruit yield and biomass waste production of 14.85 ton/ha and 15 ton/ha, respectively [2]. Stalks from passion fruit (composed mainly of hemicellulose, cellulose and lignin) are the main waste resulting from pruning during the growth or renewal of plantations. These lignocellulosic materials are frequently abandoned in the fields, treated as common trash or burned without control. To avoid the environmental impact of these practices and to valorize lignocellulosic biomass, innovative alternatives have been proposed, among which the transformation into cellulose nanocomposite materials stands out [3].

Cellulose is the most abundant renewable natural biopolymer on earth; it is present in plants and is their main structural constituent. Nanocellulose can be produced by different methods, such as high-pressure homogenization, microfluidization and mechanical fibrillation processes, and it is obtained from wood-like materials such as sugar beet, kenaf, and hem [4,5]. Interest in cellulose nanofibers has

*Corresponding author: ceorregoa@unal.edu.co increased due to their low thermal expansion, strengthening effects and high aspect ratio, and they have many applications in the nanocomposite, papermaking, and food packaging industries, among others [6-9].

Enzymes are biocatalysts that have excellent properties, such as high activity, selectivity and specificity; they are employed in different industries because of their capacity to work in complex chemical processes under harsh environmental conditions [9].

Proteases are enzymes with proteolytic activity widely used in medical and industrial application, among which trypsin is the most studied [10]. Trypsin is an animal derived globular proteolytic enzyme (endopeptidase) with good water solubility, efficiency, reliability, and cleavage specificity. It acts by cleaving peptide bonds involving the carboxyl groups of arginine and lysine [11,12].

Enzymes are soluble in water, and their recovery from aqueous effluents could be very expensive [13]. There are techniques for enzyme immobilization that allow its recovery and reuse, making the biocatalytic systems more efficient. The most common techniques for immobilization are encapsulation, adsorption and covalent binding. Additionally, the use of reagents for functional group activation is necessary to improve binding efficiency [14]. Enzymes have been immobilized in a wide variety of synthetic organic polymers, natural polymers and inorganic materials. Lignocellulosic biomass is a potential raw material for enzyme immobilization and one of the most commonly used 
natural carriers [15]. The carrier has to fill several characteristics as resistance to microbial and chemical degradation, the availability of a reactive functional group, preservation of physical integrity during the process and recycles, insolubility and inertness towards the reaction medium, a high diffusion coefficient and a superficial area $[16,17]$. Some authors have investigated different lignocellulosic-based supports such as green coconut, cashew apple bagasse, spent grain, sugarcane, wood cellulignin, among others [18-22]. They show that the lignocellulosic materials meet the necessary characteristics for being selected as a carrier to enzyme immobilization. However, cellulose from passion fruit crop and its possible application for the enzyme immobilization and for the production of cellulose nanofibers has not been yet evaluated. In this context, the aims of this work were to study the potential of passion fruit stalks as a source of cellulose nanofibers and as a carrier to immobilization of trypsin. The composition of raw PFS after and before the application of the chemical treatments were measured to determine the increase of cellulose. Two mechanical treatments were applied to cellulose from PFS for the production of cellulose nanofibers, and the effect of those treatments was evaluated in terms of SEM, XRD, FTIR and superficial area analysis. The immobilization of trypsin on cellulose was carried out by adsorption and covalent binding using two methodologies of activation.

\section{Experimental}

\section{Materials}

Stalks from passion fruit (Passiflora edulis Sim f.) (PFS) were obtained from a local farm (Chinchina, Colombia). The samples were sun dried until their moisture reached 9-10\%. The dried stalks were cut and ground. All the chemicals and the trypsin from bovine pancreas (E.C 3.4.21.4) were of analytical grade and were purchased from Merck and Sigma-Aldrich Co. (St. Louis, MO).

\section{Chemical Assays}

The chemical composition of the raw dried and treated PFS was analyzed by following the TAPPI test methods for Klason lignin (T222), $\alpha$-cellulose (T203), ashes (T211), and holocellulose [23]. The moisture content in raw PFS was determined gravimetrically. The analysis was carried out in triplicate.

\section{Cellulose Isolation from PFS: Pulping and Bleaching}

Cellulose fibers from PFS (CPF) were isolated by pulping and bleaching. The pulping process was carried out following the methodology described by El-Sakhawy et al. [24]. The fibers were immersed in a $15 \%(\mathrm{w} / \mathrm{v})$ sodium hydroxide aqueous solution at $80^{\circ} \mathrm{C}$ and stirred for $2 \mathrm{~h}$. The fibers were extracted and washed with distilled water. A three-stage fiber bleaching process was performed using the method described by Jonoobi et al. [25]. First, the fibers $(1: 10 \mathrm{w} / \mathrm{v})$ were submerged in a solution of $2 \%(\mathrm{w} / \mathrm{v})$ sodium chlorite and $3 \%(\mathrm{w} / \mathrm{v})$ acetic acid. The system was heated to $70{ }^{\circ} \mathrm{C}$ for $3 \mathrm{~h}$. After that, the fibers were vacuum filtered and washed with abundant distilled water until they became neutral $(\mathrm{pH} 7)$. In the second stage, the samples were transferred to a $200 \mathrm{~m} l$ vessel and exposed to a $1.5 \%$ $(\mathrm{w} / \mathrm{v})$ sodium hydroxide and $1 \%(\mathrm{w} / \mathrm{v})$ hydrogen peroxide solution followed by heating to $70{ }^{\circ} \mathrm{C}$ for $90 \mathrm{~min}$. Next, to extract the fibers, the solution was vacuum filtered, and then the fibers were washed with distilled water. The third treatment was performed by adding $1.25 \% \mathrm{w} / \mathrm{v}$ sodium chlorite and $3 \%(\mathrm{v} / \mathrm{v})$ acetic acid to the washed fibers in a liquid-to-fiber ratio of $10: 1$, heating the mixture at $70^{\circ} \mathrm{C}$ for $90 \mathrm{~min}$ and then vacuum filtering and washing with distilled water until neutral $\mathrm{pH}$. Finally, the samples were dried on a heating chamber (Binder Series FD, Binder GmbH, Germany) at $55^{\circ} \mathrm{C}$ for $24 \mathrm{~h}$.

\section{Production of Nanofibers}

Two mechanical treatments were tested for cellulose nanofiber (CNF) production. In the first experiment, a solution at $0.5 \%(\mathrm{w} / \mathrm{v})$ of bleached fiber-water was homogenized using an Ultraturrax Miccra D-1 disperser (ARTModerne Labortechnik, Germany) operated at $35000 \times \mathrm{g}$ with two exposure times (15 and $30 \mathrm{~min}$ ). The treatment was assisted or unassisted by ultrasound using an ultrasonic bath (Elma E30H, Singen, Germany) with a frequency of $37 \mathrm{kHz}$ and a power level of $240 \mathrm{~W}$. The second treatment with a $0.5 \%(\mathrm{w} / \mathrm{v})$ bleached fiber-water suspension was carried out with a common blender for 5 and $10 \mathrm{~min}$ in high-speed mode.

\section{Yield of Fibrillation}

Fibrillation measurement was carried out according to Benhamou et al. [26]. A diluted suspension of $0.25 \% \mathrm{CNF}$ solid content was centrifuged at $5000 \times \mathrm{g}$ for $30 \mathrm{~min}$ to separate the nanofibrillated fraction (located at the top) from the unfibrillated and partially fibrillated material. The sediment fraction was dried to constant weight and then placed into a desiccator. The assays were performed in duplicate for the samples treated with the homogenizer for 15 and $30 \mathrm{~min}$. The yield of the nanofibrillated fraction was determined using the following equation:

$$
\text { Yield }(\%)=\left[1-\frac{W_{d s}}{W_{d s} * \% S_{c}}\right] \times 100
$$

where $\% S_{c}$ is the solid content of the dilution and $W_{d s}$ is the weight of the obtained dried sediment.

\section{Scanning Electron Microscopy (SEM)}

The morphology of the fibers (raw material and fibers after chemical and mechanical treatments) was observed using a scanning electron microscope (FEI QUANTA 250, 
FEI, Czech Republic) with an accelerating voltage of $30 \mathrm{kV}$. The samples were sputter coated with gold prior to SEM analysis.

\section{FTIR Spectroscopy}

The effect of the pulping, bleaching and mechanical treatments on the surface chemistry of the nanofibers was examined using a Fourier transform infrared spectrophotometer (Model NICOLET iS5, Thermo Scientific, Madison, US) with a transmission iD1 accessory. The data were collected over 64 scans with a resolution of $4 \mathrm{~cm}^{-1}$ in the range of 4000 to $500 \mathrm{~cm}^{-1}$.

\section{X-ray Diffraction Analysis}

The XRD patterns for the raw material and cellulose fibers after bleaching process were measured with an X-ray diffractometer (Miniflex II, Rigaku, Japan) using Ni-filtered $\mathrm{Cu} \mathrm{K} \mathrm{K}_{\alpha}$ radiation $(\lambda=1.5406 \AA)$ at $30 \mathrm{kV}$ and $15 \mathrm{~mA}$. The scattered radiation was detected between $2 \theta=5-45^{\circ}$ at a scan rate of $2 \% \mathrm{~min}$ in continuous scan mode. The crystallinity index $(C I)$ was calculated from the height of the 200 peak $\left(I_{200}, 2 \theta=22.6^{\circ}\right)$ and the intensity minimum between the peaks at 200 and $110\left(I_{a m}, 2 \theta=18^{\circ}\right)$ using the Segal method [27].

$$
C I=\frac{I_{200}-I_{a m}}{I_{200}} \times 100
$$

\section{Adsorption and Superficial Area}

Nitrogen adsorption-desorption isotherm of bleached PFS fibers was determined following the methodology described by Macias-Quiroga et al. [28] in a Micrometrics ASAP 2020 instrument at $77 \mathrm{~K}$ after outgassing the samples for $1 \mathrm{~h}$ at $90{ }^{\circ} \mathrm{C}$ followed by $3 \mathrm{~h}$ at $400{ }^{\circ} \mathrm{C}$ in a vacuum. The specific surface area (BET) was measured by means of BET equation and the total pore volume was evaluated for nitrogen uptake at a relative pressure of 0.99 .

\section{Enzyme Immobilization \\ Support Activation}

The preparation of the support for immobilization of trypsin was carried out as described by Machado et al. and Bezerra et al. with some modification [29,30]. Cellulose fiber from passion fruit stalks (CPF) after chemical and mechanical treatments was activated using glycidol $(2,3-$ epoxy-propanol), glutaraldehyde, and ethylenediamine.

\section{Glycidol Modification ( $G-C P F)$}

Two hundred milligrams of fibers were resuspended in $3 \mathrm{~m} l$ of deionized water, followed by the addition of $0.476 \mathrm{ml}$ of $1.7 \mathrm{M}$ sodium hydroxide with $0.0136 \mathrm{~g}$ of sodium borohydride. The mixture was placed in an ice bath, $0.5 \mathrm{~m} l$ of glycidol was gently added dropwise, and the mixture was agitated for $18 \mathrm{~h}$ at $4{ }^{\circ} \mathrm{C}$. The support was separated by filtration and washed with 10 volumes of deionized water. To activate the glyceryl groups, the filtrated support was resuspended in $0.4 \mathrm{~m} l$ of sodium periodate $(100 \mathrm{mM})$ and $3.2 \mathrm{~m} l$ of deionized water, and the mixture was left to oxidize for $2 \mathrm{~h}$ and then washed with deionized water [31].

Inclusion of Amino Groups (EDA-G-CPF)

G-CPF reacted with $2.5 \mathrm{ml}$ of $\mathrm{pH} 10$ ethylenediamine $(2 \mathrm{M})$ for $2 \mathrm{~h}$, followed by the addition of $2.5 \mathrm{mg}$ of sodium borohydride to reduce Schiff bases into stable amines. The mixture was agitated for $2 \mathrm{~h}$. The support was then washed with 4 volumes of $\mathrm{pH} 4$ sodium acetate buffer $(0.05 \mathrm{M}), \mathrm{pH}$ 9 sodium borate $(0.05 \mathrm{M})$ and 10 volumes of deionized water. Glu-EDA-CPF was prepared through the bonding of glutaraldehyde to the amino groups by the addition of $3.5 \mathrm{ml}$ of a $\mathrm{pH} 7.0$ phosphate buffer $(0.05 \mathrm{M})$ that contained glutaraldehyde $(3 \mathrm{mM})$. The system was agitated for $2 \mathrm{~h}$ and was filtrated and washed with 20 volumes of $\mathrm{pH} 7$ phosphate buffer $(50 \mathrm{mM})$ and deionized water [32]. All treatments were performed in triplicate.

\section{Immobilization Procedure}

Trypsin immobilization was carried out by adsorption and covalent attachment using the supports that were modified with only glycidol (G-CPF) or were further modified with ethylenediamine and glutaraldehyde (Glu-EDA-CPF).

The immobilization procedure was conducted as described by Rocha et al. [32]. $20 \mathrm{mg}$ of trypsin and $200 \mathrm{mg}$ of support were resuspended in $5 \mathrm{ml}$ of a $\mathrm{pH} 10$ carbonate buffer $(0.05 \mathrm{M})$ to immobilize on G-CPF, and $5 \mathrm{ml}$ of a pH 7 buffer phosphate $(0.05 \mathrm{M})$ to immobilize on Glu-EDA-CPF. To immobilize by adsorption, $5 \mathrm{~m} l$ of a $\mathrm{pH} 8$ Tris- $\mathrm{HCl}$ buffer $(0.05 \mathrm{M})$ was used. The systems were kept under mild agitation for $18 \mathrm{~h}$ at $4{ }^{\circ} \mathrm{C}$ using a tube rotator (analog tube rotator MX-RD-E, Scilogex, USA).

\section{Protein Load Assay}

The amount of trypsin linked by covalent attachment on G-CPF and Glu-EDA-CPF and by adsorption attachment was determined using the difference between the amount of protein in solution before and after immobilization and that in the washing solution by the method of Bradford [33]. The washings were done with Tris- $\mathrm{HCl}$ buffer $(0.05 \mathrm{M})$ at $\mathrm{pH} 8.0$ in presence of $\mathrm{CaCl}_{2}(0.02 \mathrm{M}$ ) (so with reduced autolysis of trypsin). $10 \mu l$ of the samples was mixed with $300 \mu l$ of Bradford reagent, and the absorbance was read at $595 \mathrm{~nm}$ using a microplate reader (Synergy HT, Bio-Tek, USA) and bovine serum albumin was used as reference. The efficiency of immobilization was estimated from mass balances evaluated in terms of the protein coupling yield as follows [34]. The protein coupling yield was interpreted as the immobilization yield.

$$
\text { Protein coupling yield }(\%)=\frac{\text { total protein coupled }}{\text { total protein introduced }} \times 100
$$




\section{Measurement of Trypsin Activity}

The enzymatic activity of the immobilized system and of the native free enzyme was measured by monitoring the hydrolysis of $\mathrm{N}$ - $\alpha$-benzoyl-DL-arginine-p-nitroanilide (BAPNA) in Tris- $\mathrm{HCl}$ buffer $(0.05 \mathrm{M})$ with $\mathrm{CaCl}_{2}(0.02 \mathrm{M})$ at $\mathrm{pH} 8.0$, following the methodology described by Rocha et al. with some modifications [22]. For the free enzyme, $43.3 \mathrm{mg}$ of BAPNA was dissolved in $2 \mathrm{~m} l$ of dimethylsulfoxide, and the buffer solution was added to the mixture to bring the total volume up to $100 \mathrm{~m} l$. The reaction was monitored and was carried out at $25^{\circ} \mathrm{C}$ in $3 \mathrm{ml}$ cells, and the rate of $p$ nitroaniline formation was determined by measuring the absorbance at $410 \mathrm{~nm}$ in a UV-vis spectrophotometer (V560, Jasco, Japan).

To measure the activity of the immobilized system, $200 \mathrm{mg}$ of the support with enzyme was mixed with $50 \mathrm{ml}$ of BAPNA $(0.43 \mathrm{mg} / \mathrm{m} l)$ and kept under agitation for $1 \mathrm{~h}$ at $25^{\circ} \mathrm{C}$. Samples of $0.5 \mathrm{~m} l$ were collected at $0,2,4,6,8,10$, $20,30,40,50$, and $60 \mathrm{~min}$ of reaction. The reaction was stopped by the addition of $0.25 \mathrm{~m} l$ of $30 \%$ acetic acid (v/v) and placed in an ice bath. The support was separated from the samples by centrifugation at $5000 \times \mathrm{g}$ for $5 \mathrm{~min}$ (Mikro120, Hettich, UK). The absorbance was measured at $410 \mathrm{~nm}$ in a microplate reader (Synergy HT, Bio-Tek, Winooski, VT, USA). The activity retention was measured as the ratio of the remaining activity from immobilized systems to the activity of native trypsin at the same protein load [32]. The experiments were performed in triplicate. The activity was calculated as follows:

$$
\text { Activity }\left(\mathrm{U} / \mathrm{mg}_{\text {protein }}\right)=\frac{\text { slope } \times D_{f} \times V(\mathrm{~m} l)}{8.8\left(\frac{\mathrm{m} l}{\mu \mathrm{mol} \cdot \mathrm{cm}^{-1}}\right) \times m_{p}(\mathrm{mg})}
$$

where $D_{f}$ is the dilution factor, $V(\mathrm{~m} l)$ is the volume of the reaction, $m_{p}(\mathrm{mg})$ is the mass of the immobilized protein, and 8.8 is the extinction coefficient [22].

\section{Statistical Analysis}

Statistical significance difference was assessed by ANOVA using Origin Pro 8.1 software. Each analysis was performed at least in duplicate. Differences were reported as significant at $p<0.05$, and the results are expressed as the mean \pm standard deviation.

\section{Results and Discussion}

\section{Chemical Assays}

Table 1 shows the chemical composition of the raw material, pulped fiber, bleached fiber, and mechanically treated fiber of passion fruit stalks. As expected, the chemical treatment increased the cellulose content and removed the other compounds. The raw material had the highest percentage of hemicellulose and lignin and the lowest percentage of $\alpha$-cellulose. After the pulping process, the relative increase of cellulose with respect to the value in the raw PFS was near to $139 \%$, while the hemicellulose and lignin presented a relative decrease around $34 \%$ and $33 \%$, respectively. After the last stage of the bleaching process, the relative increase of cellulose was approximately $218 \%$ (see Table 1), and the hemicellulose and lignin concentrations presented a relative decrease around $54 \%$ and $96 \%$, respectively, with respect to their values in the raw PFS. The comparative chemical composition results presented in this paper for pulping and bleaching PFS were similar to those reported by El-Sakhawy et al. [24] for cotton stalks and by Jonoobi et al. [25] for kenaf fibers. The chemical treatments applied for the removal of lignin and hemicellulose from passion fruit stalks disrupt the polymeric matrix and offer high accessibility to the hydroxyl groups present in the vegetal fibers [35], turning the cellulose fibers in an optimal carrier for immobilization.

\section{Fibrillation Yield}

Figure 1 shows the photographs of PFS before the bleaching process and after the homogenization treatment (15 and $30 \mathrm{~min}$, one cycle). Fibrillation yields of $92.3 \pm$ $1.4 \%$ and $93.6 \pm 0.9 \%$ were obtained by homogenization treatments for 15 and $30 \mathrm{~min}$, respectively. Similar values were obtained by Benhamou et al. for palm tree CNF using 15 cycles of high-pressure homogenization [26]. Although

Table 1. Chemical composition of raw, chemically treated, and blended PFS

\begin{tabular}{|c|c|c|c|c|c|c|}
\hline Sample (wt) & $\begin{array}{c}\text { Cellulose } \\
(\%)\end{array}$ & $\begin{array}{l}\text { Relative increase } \\
\text { of cellulose* }(\%)\end{array}$ & $\begin{array}{c}\text { Hemicellulose } \\
(\%)\end{array}$ & $\begin{array}{l}\text { Lignin } \\
(\%)\end{array}$ & $\begin{array}{l}\text { Ash } \\
(\%)\end{array}$ & $\begin{array}{c}\text { Moisture } \\
\text { content }(\%)\end{array}$ \\
\hline Raw PFS & $36.7 \pm 0.8$ & Control & $29.1 \pm 1.7$ & $13.7 \pm 2.8$ & $12.1 \pm 3.4$ & $9.7 \pm 0.2 \%$ \\
\hline PFS fiber - after pulping & $53.1 \pm 1.0$ & $139.8 \pm 0.5$ & $19.3 \pm 0.7$ & $9.2 \pm 2.6$ & $4.2 \pm 1.3$ & $5.8 \pm 0.2 \%$ \\
\hline Bleached PFS fiber & $80.3 \pm 1.9$ & $218.8 \pm 0.6$ & $13.5 \pm 1.2$ & $0.49 \pm 0.2$ & n.d & $5.7 \pm 0.2 \%$ \\
\hline Bleached blender PFS fiber 10 min & $80.1 \pm 2.7$ & $218.2 \pm 3.7$ & $11.6 \pm 2.1$ & $0.58 \pm 0.1$ & n.d & $6.9 \pm 0.3 \%$ \\
\hline Bleached homogenizer PFS fiber $30 \mathrm{~min}$ & $80.2 \pm 1.6$ & $218.8 \pm 0.6$ & $12.0 \pm 1.9$ & $0.46 \pm 0.1$ & n.d & $6.6 \pm 0.2 \%$ \\
\hline Bleached cotton stalks [24] & 75.1 & - & 19.3 & 0.9 & n.r & n.r \\
\hline Bleached kenaf pulp [25] & $92.0 \pm 1.4$ & - & $5.2 \pm 0.6$ & $0.53 \pm 0.4$ & n.r. & n.r \\
\hline
\end{tabular}

n.r.: Not reported. n.d: Not detected, *The relative increase was calculated with respect to the initial value in Raw PFS. 

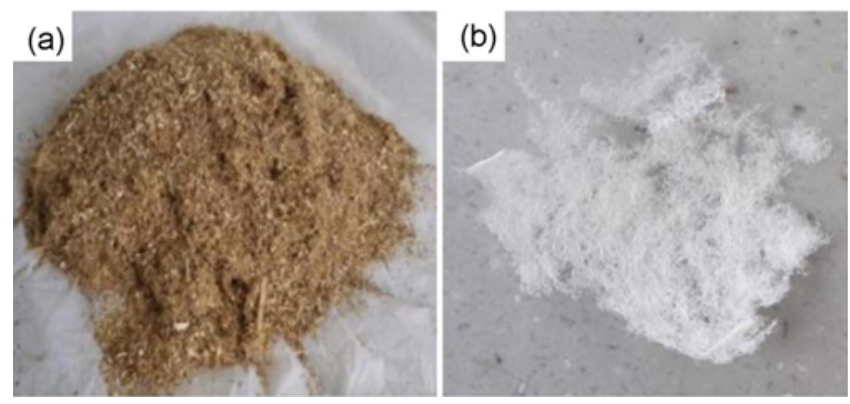

Figure 1. (a) Raw PFS material and (b) bleached homogenizer fiber at $30 \mathrm{~min}$. the raw materials were not the same, apparently, the procedure used here allows for obtaining relatively high fibrillation yields with a simple and low-energy-consumption approach.

\section{SEM Micrographs, Diameter Size, and Size Distribution Estimation}

Figure 2 shows the microstructures and surface morphologies of the PFS fibers before and after chemical treatments. The surface and interior structures changed after all chemical and mechanical treatments. On the surface of the raw PFS fibers (Figure 1a), some crusts, probably wax and greasy substances, can be observed. These impurities are scarce or absent in the
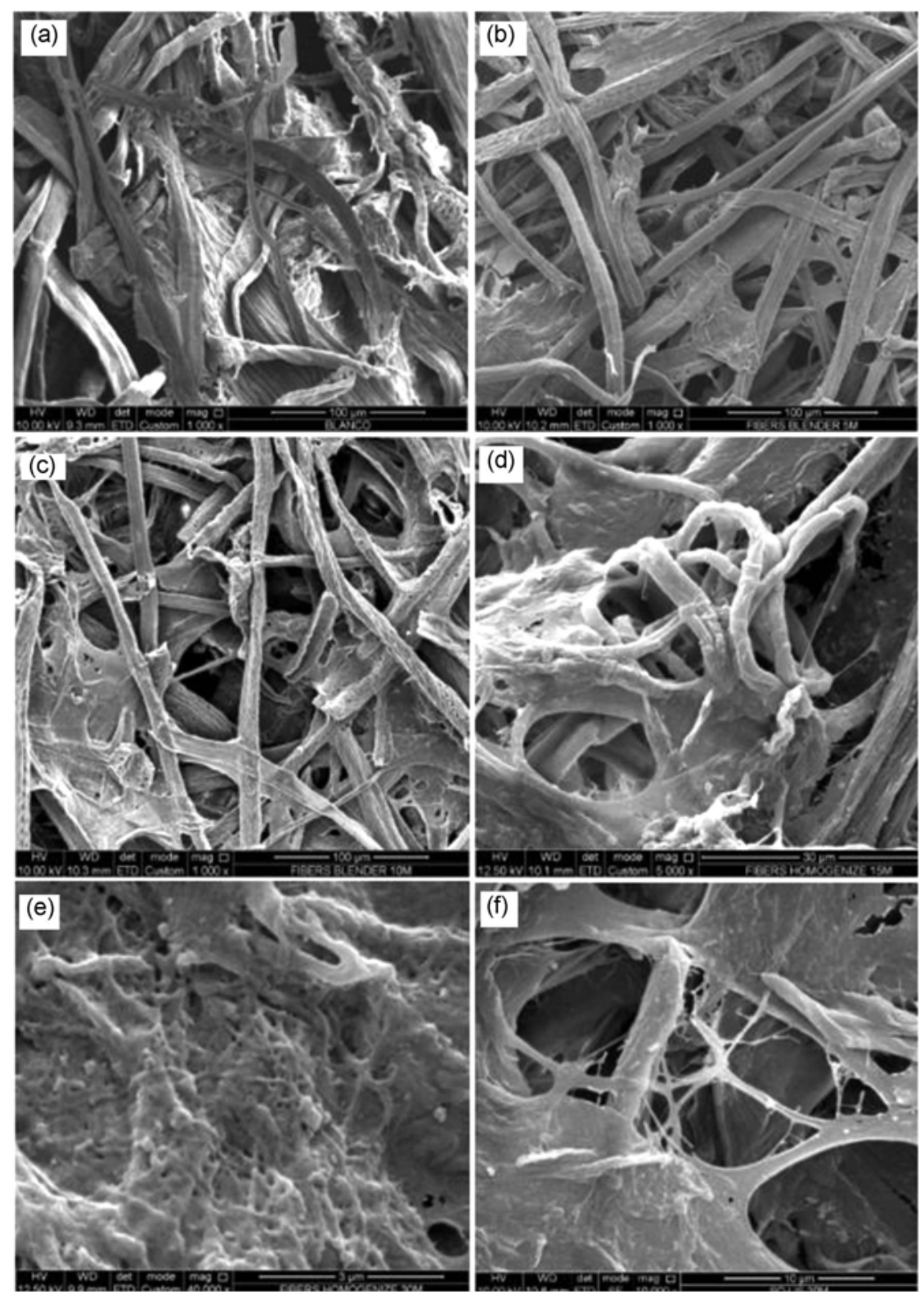

Figure 2. SEM of raw PFS fiber (a), bleached blender fiber (5 and $10 \mathrm{~min}$ ) (b, c), bleached homogenizer fiber (15 and $30 \mathrm{~min})$ (d, e), and bleached homogenizer-ultrasound fiber (f). 

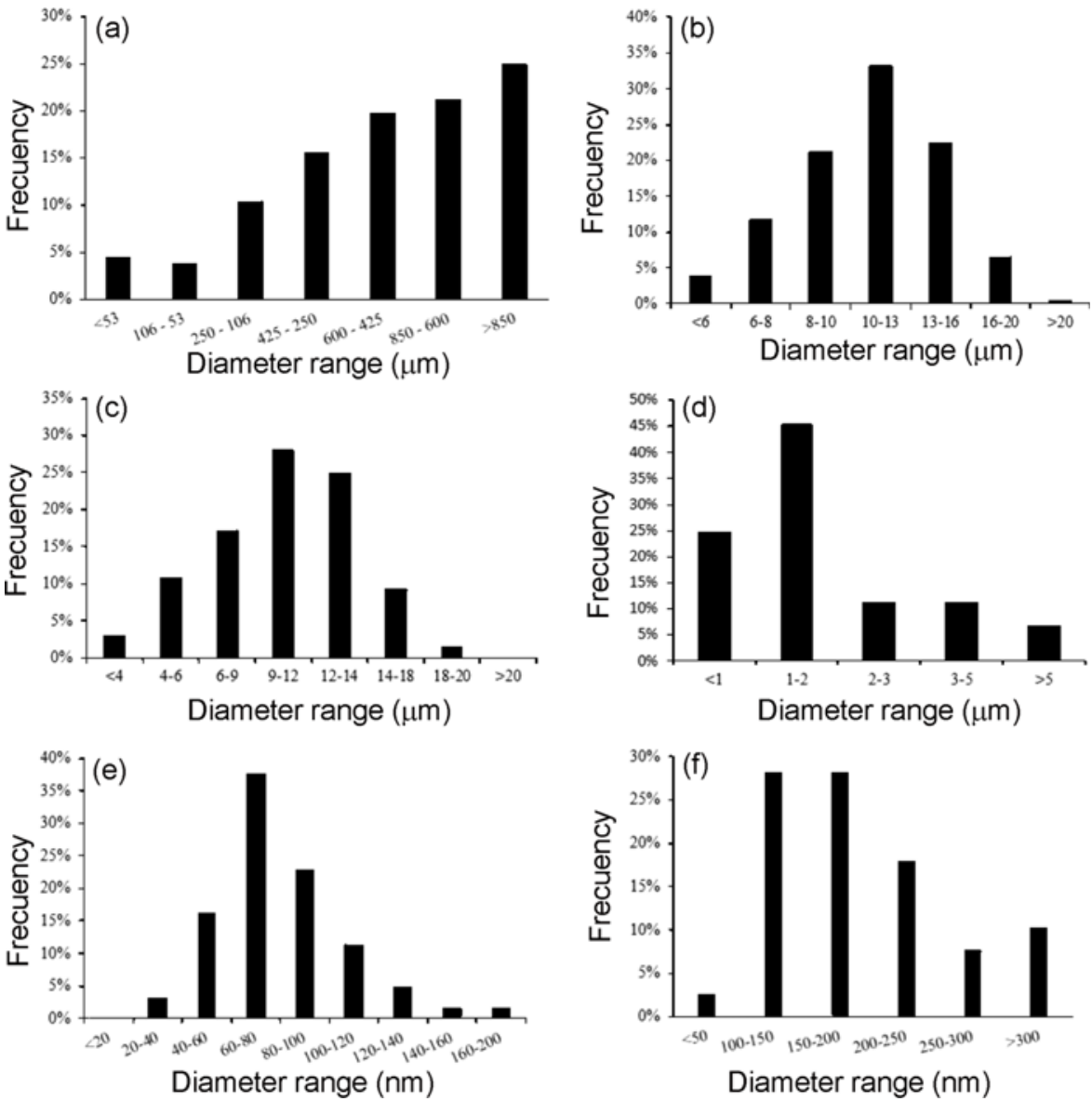

Figure 3. Diameter size distribution of raw PFS fiber (a), blended fiber (5 and $10 \mathrm{~min}$ ) (b, c), bleached homogenizer fiber (15 and 30 min) (d, e), and bleached homogenizer-ultrasound fiber (30 $\mathrm{min})(\mathrm{f})$.

treated PFS fibers (Figure 2c-f). The increase in cleanness of the treated fiber surface can be explained by the partial removal of lignin and hemicelluloses from these fibers [26]. The mean diameter size distribution was determined by measuring the diameter of 80 particles localized within a selected area (approximately $90 \%$ ) of the SEM images (Figure 2) using the image processing and analysis software ImageJ [36].

Figure 3 shows the diameter size distribution. The average diameter size of the blended fiber and chemically treated fibers did not show significant differences $(p>0.05)$ between the blending treatments. The mean diameter sizes for the 5and 10-min blended fibers were $11.3 \pm 3.2 \mu \mathrm{m}$ and $10.9 \pm 4.8 \mu \mathrm{m}$, respectively. The diameter ranges of the blended fibers were higher than those of the $80-250 \mathrm{~nm}$ nanofibers obtained by Duan et al. during the isolation of cellulose nanofibers from jute using a blender combined with chemical pretreatments after blending 20 times [37].

The average diameter size of homogenized fibers was significantly different $(p<0.05)$ from those observed for raw PFS. The size distribution of cellulose nanofibers obtained by homogenization ranged amid 20 and $200 \mathrm{~nm}$, and that obtained by homogenization assisted with ultrasound presented a size from 50 to $300 \mathrm{~nm}$. The application of ultrasound did not affect the size reduction $(p>0.05)$.

The mechanical processes described reduced the average sizes of the treated and dried fibers of PFS with respect to their original sizes. Similar results were obtained by Jonoobi et al. [25] using the cryocrushing method described by Benhamou et al. [26] with high pressure homogenization. In these two studies, $40 \mathrm{~nm}$ and $30 \mathrm{~nm}$ mean diameters were obtained, respectively. However, the homogenization process in this study was conducted with a homogenization treatment of just one short cycle, with presumably lower energy consumption than that for the methods used in the cited works.

\section{FTIR Analysis}

Figure 4 shows the FTIR spectra of the raw PFS and treated PFS fibers. The region of the spectra between 3750 and $3600 \mathrm{~cm}^{-1}$ is characteristic of nonhydrogen-bonded hydroxyl groups (isolated or free hydroxyl groups) and 


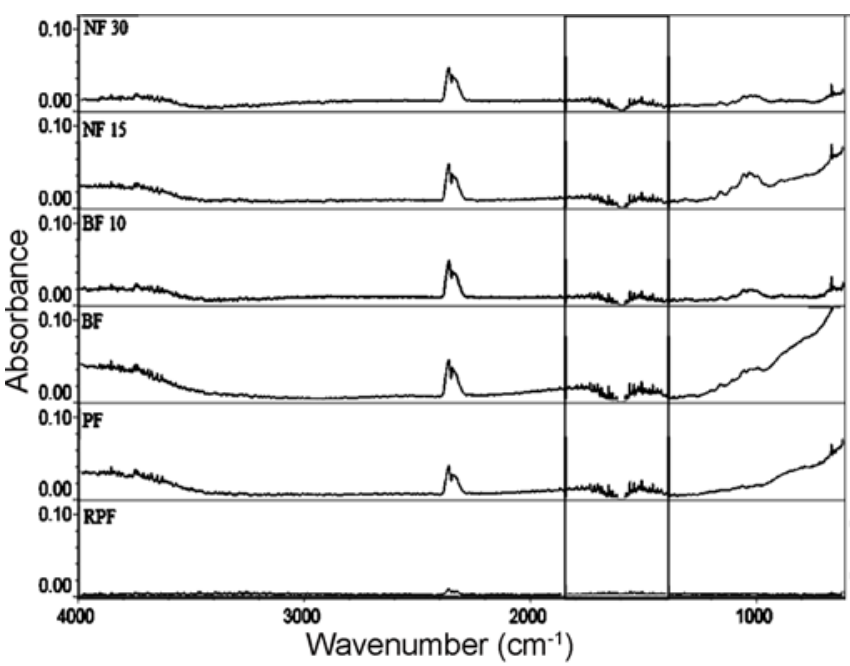

(a)

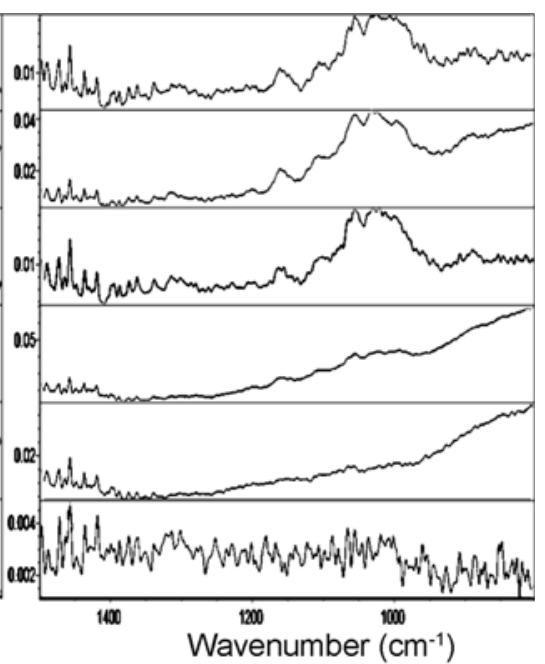

(b)

Figure 4. FTIR spectra of raw passion fruit (RPF) stalks, pulped and chemically treated PFS fiber (PF), bleached and chemically treated PFS fiber (BF), bleached blender PFS fiber/10 min (BF 10), bleached homogenizer PFS fiber/15 min (NF15), and bleached homogenizerultrasound PFS fiber/30 min (NF 30); (a) wavenumber between $4000 \mathrm{~cm}^{-1}$ and $500 \mathrm{~cm}^{-1}$ and (b) wavenumber between $1500 \mathrm{~cm}^{-1}$ and $500 \mathrm{~cm}^{-1}$.

stretching vibrations of $\mathrm{C}-\mathrm{H}$ bonds of the hydrogen-bonded hydroxyl group [38]. The PFS fibers after mechanical treatments (BF10, NF15 and NF 30) showed a new absorption band at $1156-1162 \mathrm{~cm}^{-1}$, which can be attributed to the stretching vibration of the $\mathrm{C}-\mathrm{OH}$ ring [39]. The presence of this band is associated with an increase in cellulose content in these samples and the removal of lignin and hemicellulose.

\section{X-ray Diffraction Analysis}

The index of crystallinity of native cellulose was obtained by the peak height method. Figure 5 is a comparison of the XRD diffraction profile for raw PFS and treated bleached PFS fiber. The fibers of the treated sample showed an increase in crystallinity. The crystallinity index was measured from the peaks at $I_{a m}\left(18^{\circ}\right)$ and $I_{200}\left(22.5^{\circ}\right)$. The raw PFS showed a small peak at $2 \theta=22.5^{\circ}$ and no peak at $2 \theta=18^{\circ}$, with a $C I$ of $13 \%$. Treated PFS fiber showed the presence of two of the three peaks characteristics of lignocelulosic materials (Figure 5b) [40]: peaks at $2 \theta=14.8^{\circ}, 22.5^{\circ}$ in bleached PFS fiber were observed, with a $C I$ of $47.8 \%$. The $C I$ of the cellulose rises more than three times after all the chemical and physical treatments. The changes in the crystallinity of raw PFS could be due to the removal of lignin and hemicellulose (present in the amorphous regions) during the pulping and bleaching processes [41]. These results are similar with those reported by El Halal et al. [42], that found peaks at $2 \theta=15.4^{\circ}, 22.7^{\circ}$, and $34.5^{\circ}$ for barley husk fiber treated with alkali and bleached fiber. However, in this work the corresponding peak at $34.5^{\circ}$ was not observed; this could be due to the poor crystallinity of PFS treated in comparison with the cited works.

Regarding the process of immobilization of enzymes, a
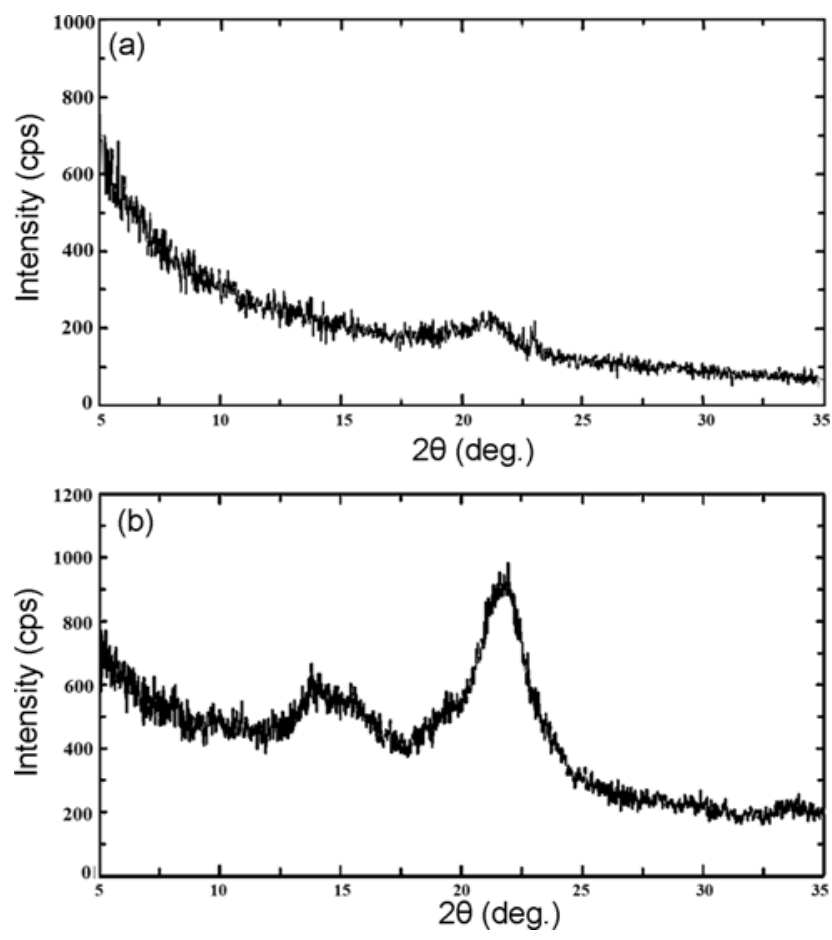

Figure 5. X-ray diffraction data for raw PFS material (a) and bleached fiber homogenized with assisted ultrasound for $30 \mathrm{~min}$ (b).

good protein load efficiency could be expected due to the increased crystallinity [43]. However, in this work, the effect of crystallinity on the protein load was not evaluated, but good yields of immobilization were obtained, as shown in Table 2. 
Table 2. Immobilization of trypsin on cellulose from passion fruit

\begin{tabular}{lcccc}
\hline \multicolumn{1}{c}{ Method of activation } & $\begin{array}{c}\text { Immobilization yield } \\
(\%)\end{array}$ & $\begin{array}{c}\text { Immobilized } \\
\text { protein (mg/g carrier) }\end{array}$ & $\begin{array}{c}\text { Activity } \\
(\mathrm{U} / \mathrm{mg} \text { protein })\end{array}$ & $\begin{array}{c}\text { Activity retention } \\
(\%)\end{array}$ \\
\hline Free enzyme & & & $2.65 \pm 0.01$ & $14.9 \pm 0.5$ \\
Adsorption attachment of CPF & $34.9 \pm 6.6$ & $1.6 \pm 0.3$ & $0.37 \pm 0.01$ & $44.0 \pm 2.0$ \\
Covalent attachment of G-CPF & $67.5 \pm 2.2$ & $2.9 \pm 0.1$ & $1.17 \pm 0.05$ & $21.2 \pm 0.7$ \\
Covalent attachment of Glu-EDA-CPF & $46.1 \pm 3.3$ & $2.3 \pm 0.2$ & $0.56 \pm 0.02$ & \\
\hline
\end{tabular}

*G-CPF: Glycidol-Cellulose Passion Fruit, ${ }^{* *}$ Glu-EDA-CPF: Glutaraldehyde- Ethylenediamine-Glycidol-Cellulose Passion Fruit.

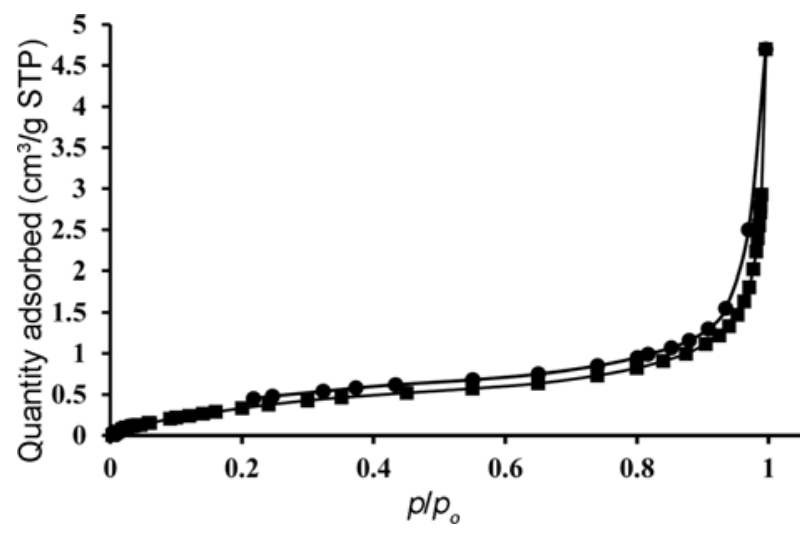

Figure 6. $\mathrm{N}_{2}$ physisorption isotherms of the bleached PFS fibers: adsorption ( $\mathbf{\square})$ and desorption $(\bullet)$.

\section{Adsorption and Superficial Area}

The isotherm to bleached PFS fibers is shown in Figure 6. It can be classified as reversible type II according to the classification of physisorption isotherms by Thommes et al. [44]. The shape is the result of unrestricted monolayermultilayer adsorption. This type of isotherm is given by the physisorption of most gases on nonporous or macroporous adsorbents [44]. BET surface area was $1.56 \pm 0.02 \mathrm{~m}^{2} / \mathrm{g}$. This result is higher than those reported by Legras et al. [45] for macroporous cellulose BioMid $^{\circledR}$ and kenaf fibers. In addition, the structure of the PFS fibers could mean that the immobilization of trypsin could be done only on the monolayer of the carrier.

\section{Immobilization of Trypsin on Cellulose Fibers}

Cellulose nanomaterials are an ideal matrix for immobilization of enzyme. However, its recuperation from the reaction medium is very difficult [46]. In order to have an easy recovery, some authors have modified the nanocellulose by incorporation of other materials [47,48]. In this work, instead of typical nanofibers, cellulose fibers slightly bigger (for easier recovery), achieved without the homogenization treatment, were used to immobilize trypsin. Trypsin was immobilized following the three methodologies mentioned above. The first procedure consisted of immobilizing the trypsin by adsorption, where physical interaction (such as van der Waals forces, ionic interactions, and hydrogen bonding) between cellulose and trypsin took place. Generally, through this technique, the enzyme does not present changes in its native structure, and the enzyme is shielded from disturbs in the active sites [46]. However, these are usually weak bonds and leakage from the support is expected to occur. In the second procedure, trypsin was immobilized by multi-point covalent binding between its amino groups from lysine and the aldehyde groups on cellulose fibers (G-CPF), taking place the formation of Schiff bases [49]. Vicinal hydroxyl groups (glyceryl groups) formed in the reaction between hydroxyl groups on the cellulose were oxidized with sodium periodate to insert aldehyde reactive groups (glyoxyl) [31,49]. In the third procedure, part of the G-CPF was further activated by the inclusion of amino groups (EDA-G-CPF); Schiff bases formed were reduced into stable amines by the addition of sodium borohydride and glutaraldehyde was used to stabilize the enzyme (it can also be used immobilize enzymes via crosslinking) [32].

The results in Table 2 show that the immobilization efficiencies for the support with chemical modification were higher than those for the simple adsorption, as expected from the nature of the bonds involved. The system modified with glycidol (G-CPF) presented an immobilization yield of $65 \%$, with a total immobilized protein content of $2.9 \mathrm{mg} / \mathrm{g}$ of support; with the support modified with Glu-EDA, the yield was approximately $30 \%$ less than that for G-CF. The differences between the immobilization yields in the G-CPF and Glu-EDA-CPF systems may be because the immobilization in G-CPF was carried out at $\mathrm{pH} 10$, presenting lower electrostatic repulsion, considering the isoelectric point of trypsin (10.5) [50]. Additionally, immobilization by multipoint covalent attachment in glycidol supports is carried out based on the enzyme lysine content. Considering the lysine reactivity, in systems activated with glycidol, immobilization must be done in an alkaline medium because at neutral $\mathrm{pH}$, lysine has poor reactivity. However, when the G-CPF system is modified with EDA and glutaraldehyde, immobilization could be achieved at close to neutral $\mathrm{pH}$ [22]. These results are also different to those reported by Silva et al. [51]; they used a similar strategy to support activation of chitosan hydrogels, and they obtained best activation thanks to the increasing in the space arm due to the addition of glutaraldehyde molecule. 
On the other hand, a similar behavior was observed in the results of activity retention. The immobilization of trypsin by covalently attaching G-CPF presented the best value (44\%) in comparison with that by covalently attaching GluEDA-CPF (21.2 \%). These differences could be due to the extra chemical treatments and the possible inactivation of the latter.

Adsorption attachment presented minor activity retention $(14.94 \%)$. Given that the adsorption process is a result of weak interactions and linkages that take place due to direct submersion, the loss of activity in this case could be ascribed to enzyme leaching. These results are supported by those of other researchers demonstrating that enzymes can be immobilized on lignocellulosic materials, such as cashew and apple bagasse, to immobilize lipase from Candida antarctica by covalent binding [19], on hydrophilic cotton and sugar cane bagasse to immobilize $\beta$-D-fructofuranosidase by adsorption and crosslinking, among others [52].

\section{Conclusion}

The protocols employed showed that it is possible to obtain cellulose nanofibers from passion fruit stalks. The chemical composition of blended fibers did not present changes after blender application, and its particle size was not affected by the use of ultrasound during the homogenization process. On the other hand, the immobilization by covalent binding using glycidol as a reagent of activation allowed us to obtain an efficient and stable proteolytic system using cellulose from passion fruit stalks. So this crop waste can be a promising carrier for trypsin immobilization. The proposed methodology showed a possible path for the successful valorization of an abundant residue from agricultural activity, thereby providing an interesting alternative to the reduction of adverse effects associated with residue treatments.

\section{Acknowledgments}

The authors acknowledge the financial support of Universidad Nacional de Colombia (Hermes code project 34573), COLCIENCIAS call 727-2015 National Doctorates. FONTAGRO (ATN/RF-16111-RG Productividad y Competitividad Frutícola Andina), and Erasmus+Programme Key Action 1. This work was also supported by the Portuguese Foundation for Science and Technology (FCT) under the scope of the strategic funding of the UID/BIO/ 04469/2020 unit and by the BioTecNorte operation (NORTE-01-0145-FEDER-000004) funded by the European Regional Development Fund under the scope of Norte2020 Programa Operacional Regional do Norte.

\section{References}

1. J. F. Morton, "Fruits of Warm Climates", Creative Resource
Systems, Inc., Miami, 1987.

2. A. MinAgricultura, Evaluaciones Agropecuarias Municipales, EVA, 2016. http://www.agronet.gov.co/estadistica/Paginas/ default.aspx (Accessed December 1, 2019).

3. H. P. S. A. Khalil, Y. Davoudpour, M. N. Islam, A. Mustapha, K. Sudesh, R. Dungani, and M. Jawaid, Carbohydr. Polym., 99, 649 (2014).

4. H. P. S. A. Khalil, Y. Davoudpour, C. K. Saurabh, M. S. Hossain, A. S. Adnan, R. Dungani, M. T. Paridah, M. Z. Islam Sarker, M. N. Fazita, M. Syakir, and M. K. M. Haafiz, Renewable Sustainable Energy Rev., 64, 823 (2016).

5. S. Beck, J. Bouchard, and R. Berry, Biomacromolecules, 12, 167 (2011).

6. M. Nogi, S. Iwamoto, A. N. Nakagaito, and H. Yano, $A d v$. Mater, 21, 1595 (2009).

7. R. J. Moon, A. Martini, J. Nairn, J. Simonsen, and J. Youngblood, Chem. Soc. Rev., 40, 3941 (2011).

8. H. Fukuzumi, T. Saito, T. Iwata, Y. Kumamoto, and A. Isogai, Biomacromolecules, 10, 162 (2009).

9. C. Mateo, J. M. Palomo, G. Fernandez-lorente, J. M. Guisan, and R. Fernandez-lafuente, Enzyme Microb. Technol., 40, 1451 (2007).

10. F. Xi, J. Wu, Z. Jia, and X. Lin, Process Biochem., 40, 2833 (2005).

11. K. Atacan and M. Özacar, Colloids Surf B., 128, 227 (2015).

12. J. Liu, Y. Liu, D. Jin, M. Meng, Y. Jiang, L. Ni, and Z. Liu, Solid State Sci., 89, 15 (2019).

13. R. A. Sheldon and J. M. Woodley, Chem. Rev., 118, 801 (2018).

14. S. Sulaiman, M. N. Mokhtar, M. N. Naim, A. S. Baharuddin, M. A. M. Salleh, and A. Sulaiman, Sains Malaysiana., 44, 1541 (2015).

15. S. F. D'souza and S. S. Godbole, J. Biochem. Biophys. Methods, 52, 59 (2002).

16. J. C. Santos, I. R. G. Pinto, W. Carvalho, I. M. Mancilha, M. G. Felipe, and S. S. Silva, Appl. Biochem. Biotechnol., 121-124, 673 (2005).

17. S. S. Silva, S. I. Mussatto, J. C. Santos, D. T. Santos, and J. Polizel, Appl. Biochem. Biotechnol., 141, 215 (2007).

18. A. I. S. Brígida, A. D. T. Pinheiro, A. L. O. Ferreira, and L. R. B. Gonçalves, Appl. Biochem. Biotechnol., 146, 173 (2008).

19. T. C. De Souza, T. D. S. Fonseca, A. Jessyca, M. Valderez, P. Rocha, M. Carlos, D. Mattos, R. Fernandez-lafuente, L. R. B. Goncalves, and C. S. José, J. Mol. Catal. B: Enzym., 130, 58 (2016).

20. F. M. Gomes, G. S. Silva, D. G. Pinatti, R. A. Conte, and H. F. De Castro, Appl. Biochem. Biotechnol., 121-124, 255 (2005).

21. A. Saeed and M. Iqbal, Biotechnol. Prog., 29, 573 (2013).

22. C. Rocha, M. P. Goncalves, and J. A. Teixeira, Process Biochem., 46, 505 (2011).

23. R. M. Rowell, R. A. Young, and J. K. Rowell, "Paper and Composites from Agro-Based Resources", p.83, CRC 
Press, 1997.

24. M. El-Sakhawy and M. L. Hassan, Carbohydr. Polym., 67, 1 (2007).

25. M. Jonoobi, J. Harun, A. Shakeri, M. Misra, and K. Oksmand, BioResources, 4, 626 (2009).

26. K. Benhamou, A. Dufresne, A. Magnin, G. Mortha, and H. Kaddami, Carbohydr. Polym., 99, 74 (2014).

27. L. Segal, J. J. Creely, A.. Martin, and C. M. Conrad, Text. Res. J., 29, 786 (1959).

28. I. F. Macías-Quiroga, G. I. Giraldo-Gómez, and N. R. Sanabria-González, Sci. World J., 2018, Article 5969178 (2018).

29. A. Machado, A. P. M. Tavares, C. M. R. Rocha, R. O. Cristóvão, J. A. Teixeira, and E. A. Macedo, Process Biochem., 47, 1095 (2012).

30. T. M. D. S. Bezerra, J. C. Bassan, V. T. D. O. Santos, A. Ferraz, and R. Monti, Process Biochem., 50, 417 (2015).

31. J. M. Guisán, Enzyme Microb. Technol., 10, 375 (1988).

32. C. M. R. Rocha, "Valorization of the Peptidic Fraction of Cheese Whey", University of Minho, http://repositorium. sdum.uminho.pt/handle/1822/8109 (2008).

33. M. Bradford, Anal. Biochem., 72, 248 (1976).

34. C. E. Orrego and J. S. Valencia, Bioprocess Biosyst. Eng., 32, 197 (2009).

35. J. Bassan, T. de Souza Bezerra, G. Peixoto, C. da Cruz, J. Galán, A. Vaz, S. Garrido, M. Filice, and R. Monti, Materials, 9, 357 (2016).

36. National Institutes of Health, ImageJ, 2016.

37. L. Duan, H. Wang, and W. Yu, Adv. Mater. Res., 651, 408 (2013).

38. C. M. Popescu, G. Singurel, M. C. Popescu, C. Vasile, D. S. Argyropoulos, and S. Willfor, Carbohydr. Polym., 77, 851 (2009).

39. M. Kacuráková, P. Capek, V. Sasinková, N. Wellner, and
A. Ebringerová, Carbohydr. Polym., 43, 195 (2000).

40. J. P. de Oliveira, G. P. Bruni, K. O. Lima, S. L. M. El Halal, G. S. da Rosa, A. R. G. Dias, and E. da R. Zavareze, Food Chem., 221, 153 (2017).

41. W. Chen, H. Yu, and Y. Liu, Carbohydr. Polym., 86, 453 (2011).

42. S. L. M. El Halal, R. Colussi, V. G. Deon, V. Z. Pinto, F. A. Villanova, N. L. V. Carreño, A. R. G. Dias, and E. D. R. Zavareze, Carbohydr. Polym., 133, 644 (2015).

43. C. E. Orrego, J. S. Valencia, and C. Zapata, Catal. Lett., 129, 312 (2009).

44. M. Thommes, K. Kaneko, A. V. Neimark, J. P. Olivier, F. Rodriguez-Reinoso, J. Rouquerol, and K. S. W. Sing, Pure Appl. Chem., 87, 1051 (2015).

45. A. Legras, A. Kondor, M. T. Heitzmann, and R. W. Truss, J. Chromatogr. A., 1425, 273 (2015).

46. Y. Liu and J. Y. Chen, J. Bioact. Compat. Polym., 31, 553 (2016).

47. S. Sulaiman, M. N. Mokhtar, M. N. Naim, A. S. Baharuddin, and A. Sulaiman, Appl. Biochem. Biotechnol., 175, 1817 (2015).

48. C. Fritz, B. Jeuck, C. Salas, R. Gonzalez, H. Jameel, and O. J. Rojas, "Cellulose Chemistry and Properties: Fibers, Nanocelluloses and Advanced Materials", 1st ed. (O. J. Rojas Ed.), pp.207-224, Springer, 2015.

49. T. Nikolic, M. Kostic, J. Praskalo, B. Pejic, Z. Petronijevic, and P. Skundric, Carbohydr. Polym., 82, 976 (2010).

50. F. J. Díaz and K. J. Blakus Jr, J. Mol. Catal. B: Enzym., 2, 115 (1996).

51. J. A. Silva, G. P. Macedo, D. S. Rodrigues, R. L. C. Giordano, and L. R. B. Goncalves, Biochem. Eng. J., 60, 16 (2012).

52. H. B. Gonçalves, J. A. Jorge, and L. H. S. Guimarães, Food Sci. Biotechnol., 24, 1429 (2015). 